\title{
Imágenes medievales de dominación en las fiestas de la Conquista: Brasil, 1500-1800
}

\author{
Jose Artur Teixeira Gonçalves \\ Universidade Estadual Paulista (Brasil)
}

\begin{abstract}
Resumen $^{1}$
Las cavalhadas coloniales brasileñas, similares a las fiestas de moros y cristianos hispánicas, que tienen como centro un conjunto de imágenes medievales de dominación serán analizadas en el presente artículo. Se tratan las metamorfosis de la fiesta, abordando las apropiaciones y la construcción de nuevos significados de los temas medievales y sus representaciones en el interior de la sociedad colonial. El objetivo de este trabajo es hacer una contribución a los estudios coloniales latinoamericanos, en cuanto a las representaciones procedentes de la península ibérica y sus mutaciones en suelo iberoamericano.
\end{abstract}

Palabras clave: BRASIL COLONIAL, FIESTAS, CONQUISTA, IMÁGENES MEDIEVALES

\begin{abstract}
The Brazilin colonial cavalhadas, similar to certain Hispanic celebrations of moros y cristianos, in that they center around medieval images of domination, will be analyzed in this article. This article will address the metamorphosis of the celebration, discussing the appropriations and the construction of the new meanings of the medieval themes and their representation within colonial society. The objective of this article is to make a contribution to Latin-American cultural studies, in regard to the representations taken from the Iberian Peninsula and their later mutations, once landed on American soil.

Palabras clave: BRAZIL COLONIAL, CELEBRATION, CONQUEST, MEDIEVAL IMAFIESTAS, CONQUISTA, MEDIEVAL IMAGES
\end{abstract}

\footnotetext{
${ }^{1}$ Una versión preliminar de este texto fue leída en el seminario nacional El avesso de la Modernidad: otros 500, Universidad Provincial de Londrina, Brasil, 16 de junio de 2000, en la sección de comunicaciones: "Los descubrimientos y el encuentro con el otro", que presidí.
} 
Los indios son obligados a escupir cada vez que hablan de cualquiera de sus dioses. Son obligados a bailar danzas nuevas, el Baile de la Conquista y el Baile de Moros y Cristianos que celebran la invasión de América y la humillación de los infieles.

Eduardo Galeano ${ }^{2}$

Las cavalhadas coloniales brasileñas, "moriscas" similares a las fiestas de moros y cristianos hispánicas, tienen como centro un conjunto de imágenes medievales de dominación cuya inserción en el Nuevo Mundo, especialmente en la América portuguesa, será analizada en el presente artículo. En otra ocasión tuvimos la oportunidad de abordar, desde el punto de vista morfológico, el "idioma medieval de la fiesta" (gestos, juegos, tramas, personajes), gestado en la larga duración y adaptado al contexto colonial ${ }^{3}$. Aquí trataremos de las metamorfosis de la fiesta, abordando las apropiaciones y la construcción de nuevos significados de los temas medievales y sus representaciones en el interior de la sociedad colonial.

Lo que se pretende es hacer una contribución a los estudios coloniales latinoamericanos, no sólo relativos a este tema ${ }^{4}$, sino también en lo concerniente a las representaciones procedentes de la península ibérica y sus mutaciones en suelo iberoamericano. En este sentido, las fiestas se constituyen en un campo privilegiado de observación, por mimetizar, como conjunto de representaciones, las relaciones de poder que se establecen en la sociedad, ya sea afirmándolas (a través de las fiestas oficiales, cívicas y religiosas) o negándolas (en ritos de inversión). Las cavalhadas sufrieron ambos tipos de apropiaciones, tanto como vehículos de la ideología del colonizador, como "contaminadas" por reapropiaciones populares. Sobre la primera manifestación nos detendremos en este estudio 5 .

\footnotetext{
2 Eduardo Galeano, "Dominus Vobiscum”, en As caras e as máscaras (Rio de Janeiro: Nova Fronteira, 1985), 75.

${ }^{3}$ José Artur Teixeira Gonçalves, "Cavalhadas na América portuguesa: morfologia da festa", en István Jancso e Iris Kantor, eds., Festa: cultura e sociabilidade na América portuguesa (São Paulo: Edusp; Hucitec, 2001), 2: 951-965.

${ }^{4} \mathrm{Sin}$ la pretensión de elaborar un balance historiográfico exhaustivo del tema, indicamos algunos de los estudios más importantes para el análisis comparativo de las fiestas de moros y cristianos en la Península Ibérica y en la América española: Ángel Cantos López, Juegos, fiestas y diversiones en América española (Madrid: Mapfre, 1992); Y. Brisset Martin, Representaciones rituales hispánicas de Conquista, tesis presentada para optar al título de Doctorado en Historia, Universidad Complutense, 1988; Mário Gonçalves Viana, "As cavalhadas em Portugal e no Brasil: ensaio de história comparada", Boletim Cultural, no. 75-78 (1971-1972).

${ }^{5}$ Para un análisis de las cavalhadas como rituales de celebración del rey y de las diferentes inversiones y apropiaciones populares, ver José Artur Teixeira Gonçalves, Cavalhadas: das lutas e torneios medievais às iestas no Brasil colonial, tesis presentada para optar al título de Maestría en Historia, Assis, Faculdade de Ciências e Letras, Universidade Estadual Paulista, 1998
} 
Apriorísticamente vencedoras, en el decir de Mário de Andrade $^{6}$, las cavalhadas ritualizan la conversión de los infieles, subyugados por los cristianos. Originadas en la época de la Reconquista, las cavalhadas fueron llevadas al Nuevo Mundo en el siglo XVI y ampliamente utilizadas en la Conquista y colonización de las Américas portuguesa y española. Al ritualizar la supremacía de los cristianos, la fiesta materializaba conceptos ibéricos de la dominación de los infieles, originados en la idea de Cruzada, gestada en la Edad Media y trasformada en la aurora de los tiempos modernos. Si el enraizamiento del espíritu cruzado encuentra en la península ibérica suelo fértil, es ahí también donde se desarrollan cambios vitales. La "guerra santa en busca de indulgencias" se transforma, con los descubrimientos y la incorporación de los territorios de América, Asia y África, en "conquista evangelizadora".

La propia empresa colonial en las posesiones ultramarinas portuguesas se legitima por el propósito de conversión y evangelización de los infieles, amparada en conceptos jurídicos de origen medieval, que admitían la dominación y la esclavización de los pueblos conquistados, como observa la historiadora María Guadalupe Pedrero-Sánchez ${ }^{7}$. En el mismo sentido Eduardo Subirats indica que la Conquista es "simultáneamente expansión occidental de un ideal medieval de cruzada, originariamente anunciado en el siglo XIII, como proyección y ampliación, en dirección a Jerusalén, de la lucha hispano-cristiana contra el Islam, así como empresa humanista y moderna de los descubrimientos científicos y geográficos" ${ }^{\natural}$.

La colonización de la América portuguesa se reviste, de esta forma, de un doble carácter: por un lado un "ímpetu salvífico", justificación dominante en el universo ideológico, y por otro, se pauta en los mecanismos de producción mercantil de la era moderna que "definía las necesidades de riqueza y poder" ". La colonización se justifica por el propio don João III ante la Curia Romana, cuando trata de justificar la conquista por el "acrescentamento de nossa santa fé católica" $"$.

La fe, bajo el manto de la Iglesia católica, debería ser mantenida por la monarquía portuguesa a cualquier precio, inclusive el de la violencia, reactualizando principios de las Cruzadas. Todavía en el siglo XVII vemos al célebre padre Antonio Vieira, en la catedral de Lisboa, alabar al Papa

\footnotetext{
${ }^{6}$ Mário Andrade, Danças dramáticas do Brasil (São Paulo: Martins, 1959), 1: 99-101.

${ }^{7} \mathrm{La}$ transformación de los ideales cruzados y de los conceptos legales medievales como elemento fundador de la esclavitud colonial en la época moderna es analizado por Pedrero-Sánchez en el artículo "Da Cruzada Medieval à Escravidão Colonial”, Cadernos de Pesquisa, no. 1 (1989): 71-85.

${ }^{8}$ Eduardo Subirats, “A lógica da colonização", en Adauto Novaes, ed., Tempo e História (São Paulo: Companhia das Letras; Secretaria Municipal de Cultura, 1992), 399.

9 Fernando Novais, "Condições da privacidade na Colônia", en Laura de Mello e Souza, ed., História da Vida Privada no Brasil (Cotidiano e vida privada na América Portuguesa) (São Paulo: Companhia das Letras, 1997), $37-$ 38.

10 “Carta de D. João III, rey de Portugal, a D. Pedro Mascarenhas. Lisboa, 4 de agosto de 1539”, en Serafim Leite, Cartas dos primeiros jesuitas do Brasil (São Paulo: 1954), 101-104.
} 
Inocencio X, que había concedido indulgencias a los soldados portugueses en la "cruzada" africana, manteniendo vivos el odio racial y los ideales de cruzada ${ }^{11}$.

Las cavalhadas exhibían imágenes de la guerra, del combate de los colonizadores montados en sus caballos, que bautizaban por la fuerza a los derrotados. Jurídicamente, la "guerra justa" o "santa" legitimaba la esclavitud indígena en el siglo XVI ${ }^{12}$. En este proceso se incluyen, también, las batallas emprendidas en el campo simbólico, donde gestos, colores y palabras son manipulados para la "colonización de lo imaginario"13 de los habitantes del Nuevo Mundo. Las fiestas de la Colonia, especialmente las cavalhadas, son herederas de una semiología de violencia, que se expresa en signos y símbolos ${ }^{14}$. Violencia real, escondida bajo la alegría festiva. Violencia contra el otro no asimilado en su singularidad.

El ancestro ibérico de la cavalhada colonial, la danza de moros y cristianos, nació alrededor del siglo XII, durante la Reconquista de la Península Ibérica, invadida por los moros en el siglo VIII y hecha efectiva a partir de 1212. La fiesta cataliza la antítesis moros-cristianos, nacida en ese contexto histórico. La danza, especie de crónica de las luchas de la cristiandad contra el islam, es también la ritualización de una sociedad deseada, que busca la armonía, paradójicamente, a través de la guerra, alimentando la hostilidad contra los "infieles" y "paganos".

El odio contra el moro es fundamental en el plano de las mentalidades medievales. La lucha contra el infiel es el fin último del ideal caballeresco ${ }^{15}$. Tal sentimiento fue ejemplarmente definido por el Papa Urbano II en el sermón de la Primera Cruzada, realizado en Clermont (1095):

Que vergüenza sería para nosotros si, esa raza infiel tan justamente despreciada que degeneró la dignidad humana y es vil esclava del demonio, llevara la mejor parte

\footnotetext{
${ }^{11}$ Antonio Vieira, "Sermão da Bula da Santa Cruzada (1647)", en Sermões (Porto: Lello \& Irmãos Editores, 1959), 14: $151-181$.

${ }^{12}$ Recuerdo aquí las resoluciones de los gobernadores Luiz de Brito y Almeida (Bahia) y Antonio Salema (Rio de Janeiro), con fecha de 6 de enero de 1574, en el ítem III: "Podrán ser esclavos: a) los que sean tomados en guerra justa hechas con la solemnidad debida b) los que sean tomados por los Indios en guerra con sus contrarios; c) los que vendan a sí mismos, pasando de los 21 años”. Bastardilla nuestra. Citado en Serafim Leite, História da Companhia de Jesus no Brasil, (Lisboa: Portugália; Rio de Janeiro: Civilização Brasileira, 1938), 2: 207-208.

${ }^{13}$ Retomo la expresión de Serge Gruzinski, que analiza la "occidentalización" (y no simplemente la hispanización) de América Latina y las proyecciones pluriculturales europeas, así como sus reproducciones, en Iberoamérica. Serge Gruzinski, "Do Barroco ao Neobarroco. Fontes coloniais dos tempos pós-modernos. O caso mexicano", en Lígia Chiappini y Flávio Wolf Aguilar, eds., Literatura e História na América Latina (São Paulo: Edusp, 1993), 75-89.

${ }^{14}$ Según Ángel Cantos López, una de las características de las fiestas en América colonial hispánica era la presencia de "una carga harto sazonada de violencia, que se incrementó en América a causa de la influencia hostil nacida de la propia conquista". Cantos, Juegos, 143.

${ }^{15}$ Según Le Goff, en el periodo en cuestión "reina toda una mitología que se resume en el duelo del caballero cristiano contra el musulmán”. Jacques Le Goff, A Civilização do Ocidente Medieval, (Lisboa: Estampa, 1983), 2 : 185 .
} 
del pueblo elegido de Dios Todopoderoso [...]. De un lado estarán los miserables, privados de los verdaderos bienes y de otro, hombres acumuladores de las verdaderas riquezas; de un lado combatirán los enemigos del Señor y del otro sus $\operatorname{amigos}^{16}$.

A pesar de florecer en un periodo en el que ya se vislumbra la victoria de la cristandad (Aragón ya estaba libre de la dominación árabe) la danza de moros y cristianos está inspirada en hechos históricos del siglo VIII, recordando pequeñas victorias en medio de la efectiva derrota de los cristianos que, posteriormente, asumieron proporciones míticas.

El combate fundador de las cavalhadas se dio en el desfiladero pirenaico de Roncesvalles (778) cuando tropas carolingias se aventuraron por España. Los ejércitos de Carlo Magno conquistaron Pamplona, Huesca, Barcelona y Gerona, pero sufrieron gran mortandad en Roncesvalles, cuando sucumbieron en una emboscada preparada por montañeses vascos. En esa masacre (15 de agosto) murió parte de la elite militar carolingia. Perecieron en manos enemigas: el senescal Eggihard, el conde Anselmo y sobre todo Roldán (o Rolando), mariscal de la comarca de Bretaña, héroe recordado todavía, por sus hazañas, en los sertões del Brasil ${ }^{17}$.

La cristiandad tardó cerca de cuatro siglos para elaborar este episodio traumático, en términos de psicología colectiva, que no es ni siquiera mencionado en los Anales Reales. Un analista contemporáneo dice que, "en este año (778), el señor rey Carlos fue a España y hubo allá un gran desastre" 18 . A lo largo de los tiempos, el acontecimiento sufrió reelaboraciones ritualizadas en la fiesta: el enemigo ya no era el vasco, sino el turco; de forma semejante a lo que se verifica en los milagros, donde los derrotados son transformados en victoriosos y héroes ${ }^{19}$.

La fiesta es, de cualquier modo, una forma de catarsis. Una elaboración de un trauma, a partir de la repetición insistente. No se trata, evidentemente, de una repetición erudita de la fiesta, sino "en el sentido que Freud dio a la repetición: un esfuerzo ciego para dominar un choque perturbador, sin que el mismo, precisamente, pudiese ser situado, fechado, desarraigado del presente y finalmente gobernado". Endosando la hipótesis de Mona Ozouf, "la fiesta repetitiva, como la neurosis, manifiesta una estrategia del arcaísmo contra la angustia”, ${ }^{20}$.

El imbricamiento de la danza de moros y cristianos con el proceso de Reconquista fue muy bien analizado por Brisset Martin, quien buscó las fuentes de tales representaciones en los combates

\footnotetext{
${ }^{16}$ Citado en Ibídem, 2: 183-184.

${ }^{17}$ Cf. Luís da Câmara Cascudo, Mouros, franceses e judeus: três presenças no Brasil (São Paulo: Perspectiva, 1984), 41-49, acerca de la presencia de Roland en Brasil.

${ }_{18}^{18}$ Le Goff, A Civilização, 1: 66.

${ }^{19}$ Un interesante contraste para estas fiestas de origen cultural cristiano fue recogido por Karadzic junto a los musulmanes de Bosnia: ellos entonan cantos épicos heroicos semejantes, sobre las guerras entre moros y cristianos, pero "en sus versiones, generalmente era su propio pueblo el que vencía". Peter A. Burke, Cultura popular na Idade Moderna (São Paulo: Companhia das Letras, 1989), 75.

${ }^{20}$ Mona Ozouf, “A festa sob a Revolução Francesa”, en Jacques Le Goff y Pierre Nora, História: Novos Objetos (Rio de Janeiro: Francisco Alves, 1988), 217.
} 
sucedidos en España durante la Edad Media. Al mismo tiempo que busca la base histórica de los argumentos de las fiestas, Brisset Martin estudia las mouriscas, inspirado en el método morfológico que Propp aplica al cuento maravilloso, estableciendo variantes y elementos constantes en esos rituales ${ }^{21}$.

La primera referencia sobre la ejecución de danzas de moros y cristianos en España se remonta al siglo XII, más precisamente alrededor de 1150. La primera fiesta de que se tiene noticia, según fuentes de tercera o cuarta mano, ya que no se conservan manuscritos originales, ocurrió entre 1150 y 1151, en Lérida, en las bodas del conde de Barcelona Ramón Berenguer IV con la infanta Petronila de Aragón. La suntuosa boda (que daba al príncipe la regencia de la Corona de Aragón) ocurrió en "pleno arrebato cruzado", en la ciudad de Lérida, que acababa de ser repoblada y unida a la heredera del reino aragonés que iniciaba la dinastía catalana de Aragón ${ }^{22}$.

Fue justamente en ese siglo que se difundieron más intensamente las canciones de gesta, exaltadoras del heroísmo cristiano y de las victorias deseadas sobre los moros (entre ellas la Chanson de Roland, escrita probablemente en los últimos años del siglo XI). Tales poemas épicos aparecen comúnmente relacionados con la propaganda de la Reconquista. Ideológicamente, la Cruzada reconquistadora asocia la expansión territorial y la expansión religiosa. Ampliar rutas comerciales, conquistar dominios y recaudar almas para la Iglesia, derrotando los enemigos, no son fines contradictorios en la óptica medieval ${ }^{23}$.

Del siglo XII en adelante, las danzas de moros y cristianos van difundiéndose en todos los reinos ibéricos. Ellas se vuelven obligatorias en todas las fiestas de gran pompa de la Iglesia o de la monarquía. Brisset Martin acompaña el recorrido de su consolidación a lo largo de los siglos XIII, XIV y XV, prolongándose en el periodo moderno e indicando su frecuente utilización en las fiestas de carácter político hasta el siglo XVI, con su incorporación a los ritos paralitúrgicos y actividades misioneras de los siglos XIV a XVII.

Originadas en España y pronto asimiladas en Portugal $^{24}$, las fiestas de moros y cristianos sobrepasaron las fronteras ibéricas y adquirieron caracteres similares en diversas regiones del continente europeo. Tales diversiones integraban la reserva o repertorio de las formas culturales europeas de la Época Moderna. En Inglaterra existía el morris, bailado con bastiones o espadas,

\footnotetext{
${ }^{21}$ Brisset M., Representaciones, 229.

${ }^{22}$ Ibídem, 265-267.

${ }^{23}$ En un célebre ensayo sobre las mentalidades, Jacques Le Goff analiza las motivaciones de las Cruzadas: "A partir de 1095 individuos y masas humanas se sublevaron en la cristiandad occidental y participaron de la gran aventura de la cruzada. Ímpetu demográfico e inicio de superpoblación, codicia de las ciudades italianas, política del papado deseoso de rehacer, en vista de los infieles, la unidad cristiana; todas esas causas no explican todo, pero sí lo esencial. Es necesaria la atracción de la Jerusalén terrestre, sustituta de la celestial, el estímulo de las imágenes de la mentalidad colectiva acumuladas en su regreso. ¿Qué sería de la cruzada sin una cierta mentalidad religiosa?”. En Le Goff y Nora, História, 69.

${ }^{24}$ Para las moriscas portuguesas, ver la clásica obra etnográfica: Teófilo Braga, O povo português em seus costumes, crenças e tradições (Lisboa: Publicações Dom Quixote, 1986), 285-306.
} 
morfológicamente emparentado con la morisca española. Francia e Italia practicaban las moriscas, que también eran conocidas en Wurmlingen, en Suábia ${ }^{25}$.

En el trascurso de la época medieval a la moderna, un hecho fue conmemorado con júbilo, en todos los lugares, con grandes simulacros de combates: la reconquista de Granada, que permitió a los españoles recuperar la totalidad de su territorio. En 1492, cuando cae el reino de Granada, último bastión moro en la península, tomado de los musulmanes por los Reyes Católicos, Cristobal Colón pisa por primera vez América. La idea de cruzada reconquistadora no es abandonada: la arremetida, ahora, será en América.

\section{4}

América no es comprendida de inmediato en su singularidad. Lo nuevo es visto a través de los lentes del pasado ${ }^{26}$. En México, en 1539, veinte años después de la llegada de los españoles a América, los indios reconstruyen la conquista de Jerusalén y la toma de Rodas, creando réplicas de ciudades musulmanas y de navíos; recreando, en palabras de Serge Gruzinski, "gigantescas Disneylandias de la Cruzada", espectáculos que "operaban la transposición del imaginario occidental a América" ${ }^{27}$.

El impacto psicológico sobre los indígenas y la ritualización del "trauma" del advenimiento europeo en América es indicado también por Nathan Wachtel, autor de un estudio sobre las danzas de la Conquista y sobre las fiestas folclóricas que representan los combates y la llegada de los colonizadores españoles. Según Wachtel,

El traumatismo de la Conquista extiende sus efectos hacia los indios del siglo XX y se encuentra profundamente inscripto en sus estructuras mentales, verdadera huella del pasado en el presente. Esta persistencia, en la memoria colectiva, de un choque cuya antigüedad supera cuatrocientos años, resulta comprobado por el folklore indígena actual ${ }^{28}$.

\footnotetext{
${ }^{25}$ Cf. Burke, Cultura popular, 41; Niomar de Souza Pereira, Cavalhadas no Brasil (São Paulo: Escola de Folclore, 1984), 118; y Andrade, Danças, 99.

${ }^{26}$ Para este asunto, ver Laura de Melo e Souza, O Diabo e a Terra de Santa Cruz (São Paulo: Companhia das Letras, 1989), 371. Según esta autora, "con la inserción del Nuevo Mundo en el horizonte europeo, se verificó un desplazamiento en el universo del imaginario: las humanidades monstruosas se asociaron a los habitantes de las tierras americanas, pero, a diferencia de lo que acontecía en Europa, pasaron a ser demonizadas". Siguiendo las huellas del citado estudio, encontramos una importante contribución del análisis iconográfico, ver Ronald Raminelli, Imagens da colonização: a representação do índio de Caminha a Vieira (Rio de Janeiro: Zahar; São Paulo: Edusp/FAPESP, 1996).

${ }^{27}$ Gruzinski analiza los "efectos perversos" desencadenados por ese tipo de representación. Para los indios nahuas, representar era ser. "Así, ese injerto del imaginario occidental no operaba sino barajando el juego habitual del significante y del significado, pues los indios, que eran los actores (en el sentido occidental del término), evolucionaban por una lógica de lo hiper-real, y no por una lógica mimética". Gruzinsky, "Do Barroco", 80.

${ }^{28}$ Nathan Wachtel, Los vencidos. Los indios del Perú frente a la conquista española (1530-1570) (Madrid: Alianza Editorial, 1976), 63-93.
} 
El miedo era un recurso eficazmente utilizado para la conversión, imprimiendo en los pueblos conquistados marcas profundas, verdaderas "secuelas". Ciertamente, lo que Gruzinski y Wachtel destacan para el caso mexicano, se repitió prácticamente en todos los confines de Iberoamérica. A título de comparación, podemos recordar las fiestas de moros y cristianos en la Colombia colonial. Se trata de Acla, donde se hicieron torneos en los que los sarracenos eran derrotados por los cristianos españoles, causando mucho espanto y admiración en los indios que asistían a las justas: "Los naturales asistieron asombrados a aquel espectáculo. En él podían dar crédito a lo que presenciaban, ya que con dificultad podían discernir entre la realidad y la ficción". Como escribe Cantos López, tales fiestas tenían un nítido carácter catequizante, ya que "nada mejor que adoctrinar divirtiendo y si, al mismo tiempo, se les amedrentaba, mucho mejor" $"$.

En la América portuguesa, el moro, combatido en las cavalhadas y fiestas desde la Edad Media, era el enemigo número uno de la cristiandad, y sufre diversas metamorfosis, encarnando en los indígenas, frecuentemente "demonizados" por la Iglesia ${ }^{30}$. Como decía el apóstol José de Anchieta, para estos de la tierra, los indios, "no hay mejor predicación que la espada y la vara de hierro" ${ }^{\prime 3}$.

Un viajero francés, pintor y dibujante que contribuyó bastante a ilustrar la historia, JeanBaptiste Debret, da testimonio de la permanencia en el imaginario colectivo de estas fiestas. Asistió, en Brasil, a comienzos del siglo XIX, a una representación de cavalhadas simulando la batalla de los caballeros brasileños que "lucían antiguas armaduras portuguesas" contra caballeros españoles vestidos de "indios". Cuenta el viajero que, "belicosos y patriotas principalmente, los brasileños terminan siempre esos ejercicios, en las fiestas solemnes, con una pequeña guerra entre caballeros brasileños y caballeros españoles. Sin embargo para mayor divertimento, los pretendidos españoles se visten de indios mientras que los brasileños lucen las antiguas armaduras portuguesas" ${ }^{32}$. Aquí, en una fusión de ficción y realidad, los indios asumen el papel de dominados, derrotados por los conquistadores.

Al cotejar el relato de Debret con otros cronistas coloniales y decimonónicos, la folclorista Niomar Pereira, una de las primeras investigadoras que iniciaron un trabajo de síntesis sobre las cavalhadas brasileñas $^{33}$, subestima una importante pista que el viajero Debret presenta sobre la utilización de las cavalhadas en la aculturación de los indígenas ${ }^{34}$. Por ejemplo, vamos a

\footnotetext{
${ }^{29}$ Cantos Lopes, Juegos, 180 y 184.

30 "En el imaginario colonial", dice Laura de Mello e Souza, "los indios eran, tradicionalmente, agentes de Satán que la catequesis se esforzaba por trasformar en almas de Cristo". Laura de Mello e Souza, "Tensiones sociales en Minas en la segunda mitad del siglo XVIII", en Novais, Tempo e História, 352-353.

${ }^{31}$ José Anchieta, "Carta a Laynez. São Vicente, 16 de abril de 1563", en Leite, Cartas, 3: 554.

${ }^{32}$ Jean-Baptiste Debret, Viagem pitoresca e histórica ao Brasil, traducción de Sérgio Milliet y presentación de Mário G. Ferri (São Paulo: Edusp; Belo Horizonte: Itatiaia, 1978), 2: 264.

${ }^{33}$ Pereira, Cavalhadas.

${ }^{34}$ Según esta autora, las "informaciones" prestadas por Debret "son válidas sólo en el sentido de registrar los hechos del folguedo en este periodo, ya que, de acuerdo con las noticias de las primeras cavalhadas en Pernambuco y en Rio
} 
encontrar en Sao Paulo, en el siglo XVIII, caballos de reserva de los combatientes de las cavalhadas, "montados por indios, todos ricamente vestidos y emplumados"35. Los indios no eran únicamente los destinatarios de las fiestas de conversión, sino que formaban parte de ellas (aunque ocupasen un lugar subalterno con relación a los "heroicos" protagonistas de los torneos: los caballeros portugueses).

Aceptando lo que escribió Gilberto Freyre, en el clásico Casa Grande \& Senzala,

[...] se repitió en América, entre los portugueses diseminados por un territorio vasto, el mismo proceso de unificación que en la Península: cristianos contra infieles. Nuestras guerras contra los indios nunca fueron las guerras del blanco contra los pieles rojas, sino de cristianos contra indios bravíos ${ }^{36}$.

Desde el inicio de la colonización, los indios fueron asociados a los moros, y ante los ojos de los jesuitas, los primeros parecían más difíciles de convertir que los segundos. El padre Antônio Pires escribe a sus superiores de Coimbra, en 1552, a propósito de la fiesta del Espíritu Santo en Pernambuco: "si para convertir a los de la India y a los moros son necesarios X, en esta tierra se necesitan $\mathrm{XX}^{\prime 37}$. Los trabajos de conversión aquí demandaban el doble de los efectivos empleados en Oriente.

En el Diálogo sobre la conversión del gentio (1557), del padre Manoel de Nóbrega, son comparados nuevamente los indios con los moros. Cuando un interlocutor le pregunta "No os parecen tan bestiales los moros a quienes Mafamed convirtió a su bestial secta como estos?", el padre Nóbrega responde:

Si quieres cotejar cosa con cosa, ceguera con ceguera, bestialidad con bestialidad, las hallareis todas de un jaez, porque proceden de la misma humana ceguera. Los moros creen en Mafamede, muy vicioso y torpe, y ponen la bienaventuranza en los deleites de la carne y en los vicios, y estos dan crédito a un hechicero que les pone la bienaventuranza en la venganza de sus enemigos y en la valentía y en tener muchas mujeres ${ }^{38}$.

de Janeiro, se sabe que las vestimentas de los caballeros nunca fueron fantasías de indio o antiguas armaduras portuguesas". Ibídem, 26.

${ }^{35}$ Relação das festas públicas que na cidade de São Paulo fez d. Luís Antônio de Sousa Botelho Mourão, 1770, 61.

${ }^{36}$ G. Freyre, Casa Grande \& Senzala (Rio de Janeiro: José Olympio, 1983), 192-193.

37 "Carta del padre Antônio Pires a los padres y hermanos de Coimbra, Pernambuco, 4 de junio de 1552", en Leite, Cartas, vol 1., 324.

38 "Se queréis quoteijar cousa com cousa, cegueira com segueira [sic], bestialidade com bestialidade, todas achareis de hum jaez, que proceden de huma mesma segueira. Os mouros creem em Mafamede, muito visioso e torpe, e põelhes a bem-aventurança nos deleites da carne e nos vícios, e estes dam credito a hum feiticeiro que lhes põe a bemaventurança na vingança de seus inimigos e na valentia, e en terem muitas molheres". Manoel Lóbrega, "Diálogo sobre la conversión del gentío. Bahía, 1556-1557”, en Leite, Cartas. 
La poligamia de los indios (así como su costumbre de rezar durante la madrugada) también hicieron que el jesuita Pero Rodrigues recordara a los seguidores de la religión de Mahoma: "Me parece que esta gentilidad en algunas cosas se parece a los moros, así como en tener muchas mujeres y en predicar por las mañanas de madrugada", escribe a los jesuitas de la misión de Tetuão que catequizaba a africanos islámicos ${ }^{39}$.

\section{5}

Hábiles en la utilización del teatro y de las fiestas profanas con fines catequísticos, a pesar de las prohibiciones del Concilio de Trento $^{40}$, los religiosos, especialmente los jesuitas, aprovechaban la imbricación entre el imaginario de la Conquista y la fiesta del Espíritu Santo o Pentecostés, que va a aglutinar las fiestas de moros y cristianos en el calendario religioso.

La fiesta del Divino Espíritu Santo ${ }^{41}$, traída al Brasil en el siglo XVI, se celebraba el domingo de Pentecostés (fecha variable, celebrada 10 días después del jueves de la Ascensión del Señor, 40 días después de la fiesta de Pascua). Recuerda el momento en el que Jesús envió el Espíritu Santo a los apóstoles, encargándoles que empezaran a evangelizar a todos los pueblos. Reside en este pasaje -sobre el que volveré más adelante- el germen de la aspiración salvadora de la cristiandad medieval, que sería apropiado por las monarquías ibéricas, colonialistas y esclavistas.

En la víspera del Pentecostés de 1691, en una reducción jesuítica del Río de la Plata, una indígena profirió un discurso (traducido por un padre que entendía la lengua de los indios) que causó admiración en el jesuita alemán Antonio Sepp. El contenido de su discurso es el siguiente:

Así como el Espíritu Santo había descendido sobre los apóstoles y los había inflamado con las llamas del fuego divino para que hablaran con lenguas de fuego, y con ese fuego incendiaron el mundo entero, a fin de que éste ardiera en ese su amor; así habrían llegado ahora tantas lenguas de fuego como padres misioneros

\footnotetext{
39 “Carta del Ir. Pero Correa al pe. João Nunes Barreto, África. São Vicente, 20 de junio de 1551”, en Ibídem., 1: 225.

${ }^{40}$ En la Colonia, la actitud de la Iglesia con relación a las fiestas asumió características propias, diferentes de la Metrópoli. Mientras que, en Europa, las fiestas eran oficialmente reprimidas, en Brasil eran importante instrumento de catequesis, contrariando las normas del Concilio de Trento, que pretendía "ordenar la espiritualidad pública y sus prácticas, barriendo debajo de la alfombra las llamadas "profanaciones y abusos"'. Cf. Mary del Priore, Festas e Utopias no Brasil Colonial (São Paulo: Brasiliense, 1994), 97. Para la teatralización y catequesis jesuítica: L. F. Baêta Neves, O combate dos soldados de Cristo na Terra dos Papagaios (Rio de Janeiro: Forense-Universitaria, 1978), 37-38.

${ }^{41}$ En Portugal, la fiesta del Divino nace durante el reinado de don Diniz y doña Izabel, en el siglo XIV. Fue idealizada a partir de las ideas del monje calabrés Joaquim de Fiori, para quien el mundo había sido dividido en tres épocas: la del Padre, la del Hijo y la de Espíritu Santo, que sería marcada por la alegría. La fiesta fue adoptada por el príncipe napolitano Luis de Anjou para poner en escena el "santo-imperialismo". Cf.: La P. Moura, "Folclorofilia e Romantismo", Boletim da Comissão Mineira de Folclore, no. 11 (1987), 48; L. C. Cascudo, Folclore do Brasil (Rio de Janeiro: Fundo de Cultura, 1967), 53. Para la teoría de Fiori, ver Nachman Falbel, A luta dos espirituais e sua contribuição para a reformulação da teoria do poder papal (São Paulo: USP, 1976), 103-130.
} 
para inflamar estos pobres pueblos americanos abandonados y hacerlos arder con el fuego del amor que habían traído de la Europa distante, para que los pobres indios fueran instruidos en la fe y vivieran en el amor de Dios y, en él, pudieran morir ${ }^{42}$.

El ingenioso discurso (ciertamente filtrado por el padre superior, responsable por la traducción que Sepp transcribió en su relato) recrea en el Nuevo Mundo el mensaje religioso de Pentecostés. ¿Lo que dijo la india, era realmente de ella? Su contenido está lleno de imágenes de la narrativa de los Hechos de los Apóstoles, atribuido a Lucas, como podemos observar ${ }^{43}$ :

Cuando llegó el día de Pentecostes ${ }^{44}$, estaban todos reunidos en el mismo lugar. De repente, vino del cielo un ruido semejante al soplar de un impetuoso vendaval y llenó toda la casa donde se hallaban. Y aparecieron unas como lenguas de fuego, que se distribuyeron y fueron a posar sobre cada uno de ellos. Todos quedaron llenos del Espíritu Santo y comenzaron a hablar en otras lenguas, conforme el Espíritu los impelía a hablar (Hechos, 2; 1-4).

La imagen de las lenguas de fuego (tan caras al gusto barroco ${ }^{45}$ ) se avivaba con luces esparcidas por toda la reducción, en cuernos que ardían con sebo. Después del discurso, por la noche, la fiesta del "Pentecostés-Conquista" era celebrada con danzas bélicas, en una de las cuales seis muchachos indios aparecían a caballo, vestidos a la española, imitando las moriscas y Bailes de la Conquista. Los dominados mimetizan los papeles de los dominadores igualándose en el modo de vestir y montando caballos, símbolo de la supremacía militar de los conquistadores.

El relato de Sepp es minucioso y revela la preocupación de los jesuitas por "suscitar sentimientos de piedad en nuestros indios por medio de escenas teatrales adecuadas", o sea, adaptadas "a esta gente ruda". Cuenta el padre alemán que, "en las celebraciones de las fiestas" los jesuitas introducían "danzas que mucho divierten a los indígenas", tales como danzas pírricas (de espadas) y de argollas, que son las que se realizan en las cavalhadas.

Desgraciadamente, los jesuitas que actuaron en Brasil dejaron relatos con muchas lagunas sobre la utilización de cavalhadas y fiestas en el proceso de catequesis de los indígenas. Tal vez, con fundamentada preocupación ante las normas tridentinas, los religiosos fueron más cautelosos en los informes a sus superiores europeos, aunque, en algunos casos como los textos de Fernão Cardin, estén repletos de referencias a fiestas. Es sintomática, en este sentido, la división que

\footnotetext{
${ }^{42}$ S. J. Antônio Sepp, Viagem às missões jesuíticas e trabalhos apostólicos, traducción de Reymundo Schneider (São Paulo: Livraria Martins Editora, 1943), 110 y 111, 230.

${ }^{43}$ Utilizo la Bíblia de Jerusalém: Novo Testamento (São Paulo: Paulinas, 1978), basada en la edición francesa dirigida por la Ecole Biblique de Jérusalem.

${ }^{44}$ En la tradición bíblica, Pentecostés ya había sido fiesta de la cosecha (EX 23,14+), después fiesta de la renovación de la Alianza (2Cr 15,10-13; Jubileus 6,20, Qumrã).

${ }^{45}$ Para un análisis de la fiesta barroca, Cf. Affonso Ávila, "Festa barroca: ideologia e estrutura”, en Ana Pizarro, ed., América latina: palavra, literatura e cultura: a situação colonial (São Paulo: Memorial da América Latina; Campinas: Editora da Unicamp, 1993), 1: 235-263.
} 
hace el diccionarista del setecientos, Rafael Bluteau, entre fiestas religiosas y profanas, entre las cuales se encuentran las cavalhadas.

Una de las primeras festividades organizadas por los jesuitas en la Colonia fue narrada por el padre Manoel de Nóbrega, con ocasión del Corpus Christi del 20 de junio de 1549. Se hizo una "procesión [...] muy solemne, en la que jugó toda la artillería que estaba en la cerca, las calles estaban muy enramadas, se oían danzas e invenciones a la manera de Portugal" ${ }^{46}$. Se entiende como "danzas e invenciones a la portuguesa", según Serafim Leite: moriscas, folias y representaciones, como las realizadas en el Corpus Christi celebrado en el Puerto, en el mismo periodo. Dice el padre que los indígenas asistían "espantados sobremanera" a estos festejos.

A pesar del silencio sobre el teatro ecuestre "profano" en la catequesis, es posible inferir con cierto grado de confiabilidad su utilización en la América portuguesa. La lectura cruzada de cartas jesuíticas confirma lo que venimos afirmando como en hipótesis ${ }^{47}$ y revela los lazos existentes entre la fiesta y la conversión-colonización.

Corría el tiempo de Pentecostés, cuando Piratininga se preparaba para recibir la visita del ouvidor general João Viejo de Azevedo. Era el año de 1563, cuando se dio este acontecimiento en la Villa de Piratininga que después se haría famosa, por el éxito de las conversiones, en esta villa de São Paulo ${ }^{48}$. La época de Pentecostés, como podemos leer en Nóbrega ${ }^{49}$, era destinada a la conversión. La acogida preparada para el ouvidor se volvió una gran conmemoración por la empresa de conversión de los indígenas, llevada a cabo por los ignacianos en la América portuguesa. Nada más oportuno entonces, que celebrar Pentecostés demostrando la supremacía de los colonizadores en suelo paulista, signo de la colonización bifronte: almas para la obra de Dios y brazos para la obra del rey.

Se anunció un Jubileo para la fiesta del Espíritu Santo, que estaba próxima, para dar gracias especiales a Dios. Hubo vísperas solemnes, predicación y procesión. La villa mostró su regocijo encendiendo luminarias durante tres días; los caballeros hicieron hermoso torneo y en todas las plazas y calles se oía a cada paso el grito de ¡Viva la Compañía! $!^{50}$, exaltándose continuamente a la Compañía de Jesús. Durante la fiesta se demarcaron, como era habitual, los límites de la convivencia entre blancos e indios, subrayando jerarquías y equilibrios de la comunidad colonial ${ }^{51}$.

\footnotetext{
46 “Carta del padre Manoel de la Nóbrega al pe. Simão Rodrigues. Bahia, 9 de agosto de 1549”, en Leite, Cartas, 1: 129.

${ }^{47}$ Teixeira, Cavalhadas, 26.

${ }^{48}$ El relato trae importante información etnográfica, ya que indica la realización de cavalhadas en São Paulo antes aun antes de la primera referencia del festejo en el nordeste brasileño, que se consideraba la puerta de entrada de los torneos. Pereira, Cavalhadas, 17.

49 "Bautizamos ya cien personas poco más o menos, y comenzamos la fiesta del Espíritu Santo, que es tiempo ordenado por la Iglesia". "Carta del padre Manoel de la Nóbrega al dr. Azpicuelta Navarro. Salvador, 10 de agosto de $1549 "$ ".

${ }^{50}$ Leite, História, tomo 6, 291.

${ }^{51}$ Priore, Festas, 61.
} 
Si cotejásemos el relato con otra información jesuítica, podríamos ver que las rivalidades festivas, celebradas en los torneos de los caballeros hidalgos de la tierra en aquel momento, eran muy reales y se vinculaban fuertemente a la empresa de colonización.

En general, las relaciones cotidianas en la villa de Piratininga estaban cargadas por tensiones y contradicciones. Los jesuitas habían catequizado buen número de indios, muchos de los cuales se tornaban esclavos en manos de los colonizadores laicos. Aunque la esclavitud de los indígenas no era del agrado de los ignacianos, la villa estaba en la "frontera" con poblaciones de indios enemigos, en permanente estado de guerra con los colonizadores portugueses e indios cristianos. Y era entre los enemigos donde los portugueses buscaban brazos para consolidar la conquista del suelo.

Las permanentes tensiones tenían la villa en continuo sobresalto, más aún cuando se intensificaban las amenazas de guerra o cuando los indios enemigos mataban indios cristianos y portugueses ${ }^{52}$. Ante el asedio de estas tribus, los jesuitas buscaron protección bajo el palio bélico de los colonizadores y de los indios cristianos. Entre estos se destacó un personaje "principal" llamado Martín Alfonso Tibiriçá. Según el relato del padre José de Anchieta, Martín Afonso

[...] juntó luego toda su gente, que estaba repartida por tres aldeas pequeñas, deshaciendo sus casas y abandonando sus cosechas a la posible destrucción de los enemigos $^{53}$.

Durante los "cinco días que estuvimos a la espera del combate" -dice el jesuita- "los indios aliados aderezaron sus tropas, clamando que debían defender la iglesia que los padres habian hecho para enseñarles a ellos y a sus hijos que Dios les daría la victoria contra sus enemigos, que tan sin razón querían hacerles guerra" ${ }^{54}$. Se revive aquí el enfrentamiento entre los ejércitos del bien y las huestes del mal. Antes de entrar en campo llevaban su "bandera" y "una espada de palo muy pintada, adornada con plumas de diversos colores, que eran las señales de guerra" Los rituales bélicos de los indios se apoderan de la espada como símbolo de poder y, a su modo, la yerguen para defender a los padres y su propuesta de conversión.

Martín Tibiriçá es recordado por José de Anchieta como si fuera un Rolando, héroe de los ejércitos y defensor de la cristiandad. Heroísmo indígena que tendría eco mucho tiempo después en las páginas de la literatura romántica. Pero este es otro tema que podrá ser tratado en otro momento.

\footnotetext{
${ }^{52}$ Anchieta, “Carta a Laynez", 192.

${ }^{53}$ Ibídem, 193.

${ }^{54}$ Ibídem, 193. Bastardilla nuestra.

${ }^{55}$ Ibídem, 194.
} 
Vencidos los indios belicosos, los jesuitas trataron de cercar con baluartes toda la villa de Piratininga, junto a los portugueses. Pocos meses después de estos acontecimientos, serán los mismos portugueses y religiosos los que recibirían al ouvidor general João Viejo de Azevedo con cavalhadas y torneos ecuestres, simulando batallas y lanzando vivas a la Compañía de Jesús, como pudimos ver anteriormente. Batallas fingidas y combates reales se entrelazan, estableciendo sociabilidades y recreando símbolos de supremacía de la Conquista, a partir de las imágenes ibéricas de las luchas de moros y cristianos.

"Piratininga es una villa fruto de la invocación a la conversión de San Pablo", recordaba el padre Fernão Cardim en 1585, durante una visita del superior de la Compañía de Jesús a las obras de conversión de los paulistas. Como ocurrió con ocasión de la entrada del ouvidor general, en 1563, el visitador de los jesuitas también fue saludado con grandes fiestas, en las cuales "vinieron los principales de la villa recorriendo tres leguas para recibir al padre. Todo el camino fueron realizando escaramuzas y corriendo sus jinetes, que los hay buenos", hasta llegar a un altar donde estaba la cruz. Para rematar las carreras ecuestres, hicieron una "danza de hombres de espadas" ${ }^{\text {"56. }}$.

Del mismo modo ocurrió en el jubileo de Pentecostés, el 21 de mayo de 1564, en otra fiesta del Espíritu Santo, lo que muestra indudablemente la asociación de las cavalhadas al calendario de las fiestas del Divino, como tradicionalmente se designan estas celebraciones. Se realizaron fiestas con gran pompa, con misa, coros, Te Deum Laudamus y Laudate Dominum Omnes Gentes, bailes y procesión.

Algunos señores, para mayor regocijo de la fiesta, después de comer, corrieron las cañas en la aldea y los indios también hicieron sus bailes y danzas; todos y cada uno a su manera, alegrándose en el Señor ${ }^{57}$.

En otras ocasiones los colonos tuvieron oportunidad de utilizar las cavalhadas como rituales para simbolizar su estatus, poder y prestigio. Así fue en la boda de una "moza honrada con un viannez", en 1584, en Pernambuco. El padre Fernão Cardim asistió a la solemnidad, en la que "los parientes y amigos se vistieron, unos de terciopelo carmesí, otros de verde". Los caballos estaban adornados con los mismos colores de las mal aclimatadas vestimentas de los caballeros. "Aquel día corrieron toros, jugaron cañas, pato, argollas y vinieron hasta las puertas del Colegio para que los viese el padre visitador" $"$.

Otras diversas cavalhadas fueron realizadas en la Colonia bajo el patrocinio de la Iglesia. En Bahia, estudiantes del colegio jesuita realizaron, en 1589, un simulacro de guerra, formado por dos grupos antagónicos, con distribución de premios entre los vencedores. En Rio de Janeiro, en 1730, una explanada de la hacienda del colegio mantenida por los jesuitas, también fue

\footnotetext{
${ }^{56}$ Fernão Cardim, Tratados da Terra e Gente do Brasil (1585) (São Paulo: Companhia Editora Nacional/MEC, 1978), 312 y 313 .

${ }^{57}$ Leite, História, 2: 315.

${ }^{58}$ Cardim, Tratados, 295.
} 
escenario de grandes fiestas, con títeres de musulmanes, especie de espantajos para la Iglesia, organizadas con motivo de la visita del ouvidor general Manuel de la Costa Mimoso ${ }^{59}$. Estos rituales de catequesis mimetizan ejemplarmente las imágenes medievales de dominación en suelo iberoamericano.

\section{6}

Acompañando las narrativas sobre las cavalhadas en la América portuguesa, hemos podido percibir la reutilización de estas fiestas e imágenes ibéricas en el proceso de conversión en el Nuevo Mundo, lo que permite una reflexión sobre los múltiples significados de la fiesta en la vida colectiva. Con ocasión de las conmemoraciones de los 500 años del Descubrimiento de Brasil, el verbo más conjugado fue festejar.

Sin embargo, lo que se festeja en esos rituales es, en esencia, el advenimiento de la colonización. Cuando se habla de colonización no se pueden borrar las marcas de las violencias cometidas contra indios y negros. Violencias físicas y culturales, cuyas huellas en la sociedad no pueden ocultarse. Bajo este aspecto, todas las imágenes de dominación son imágenes perversas. Mas, si los propios colonizadores escogieron como fiesta de la Conquista un ritual que celebra la violencia contra el otro, me gustaría lanzar una pregunta: ¿Qué fiesta debemos celebrar nosotros, latinoamericanos? ${ }^{60}$

\section{Bibliografía}

Andrade, Mário. Danças dramáticas do Brasil. Vol. 1. Sao Paulo: Martins, 1959.

Ávila, Affonso. "Festa barroca: ideologia e estrutura". En Ana Pizarro, ed., América latina: palavra, literatura e cultura: a situação colonial. Vol. 1. Sao Paulo: Memorial da América Latina; Campinas: Editora da Unicamp, 1993.

Bíblia de Jerusalém: Novo Testamento. Sao Paulo: Paulinas, 1978.

Braga, Teófilo. O povo português em seus costumes, crenças e tradições. Lisboa: Publicações Dom Quixote, 1986.

Brisset Martin, Y. Representaciones rituales hispánicas de Conquista. Tesis presentada para optar al título de Doctorado en Historia, Universidad Complutense, 1988.

Burke, Peter A. Cultura popular na Idade Moderna. Sao Paulo: Companhia das Letras, 1989.

Câmara Cascudo, Luís da. Mouros, franceses e judeus: três presenças no Brasil. Sao Paulo: Perspectiva, 1984.

Cantos López, Ángel. Juegos, fiestas y diversiones en América española. Madrid: Mapfre, 1992.

\footnotetext{
${ }^{59}$ Leite, História, 6: 91.

${ }^{60}$ Me gustaría agradecer a la FAPESP (Fundação de Amparo à Pesquisa no Estado de São Paulo) por la beca que permitió la realización de esta investigación, a Adriana Samacoits por su lectura cuidadosa, así como expresar mis agradecimientos a mi maestra de siempre, Maria Guadalupe Pedrero-Sánchez.
} 
Cardim, Fernão. Tratados da terra e gente do Brasil (1585). São Paulo: Companhia Editora Nacional/MEC, 1978.

Cascudo, L. C. Folclore do Brasil. Rio de Janeiro, Fundo de Cultura, 1967.

Debret, Jean-Baptiste. Viagem pitoresca e histórica ao Brasil. Traducción de Sérgio Milliet y presentación de Mário G. Ferri. 2 vols. São Paulo: Edusp; Belo Horizonte: Itatiaia, 1978.

Falbel, Nachman. A luta dos espirituais e sua contribuição para a reformulação da teoria do poder papal. São Paulo: USP, 1976.

Freyre, G. Casa Grande \& Senzala. Rio de Janeiro: José Olympio, 1983.

Galeano, Eduardo. "Dominus Vobiscum”. En As caras e as máscaras. Rio de Janeiro: Nova Fronteira, 1985.

Gonçalves Viana, Mário. "As cavalhadas em Portugal e no Brasil: ensaio de história comparada". Boletim Cultural, no. 75-78 (1971-1972).

Gruzinski, Serge. "Do Barroco ao Neobarroco. Fontes coloniais dos tempos pós-modernos. O caso mexicano". En Lígia Chiappini y Flávio Wolf Aguilar, eds. Literatura e história na América Latina. Sao Paulo: Edusp, 1993.

Le Goff, Jacques. A Civilização do Ocidente Medieva. 2 vols. Lisboa: Estampa, 1983.

Leite, Serafim. Cartas dos primeiros jesuitas do Brasil. São Paulo, 1954.

História da Companhia de Jesus no Brasil. Lisboa: Portugália; Rio de Janeiro: Civilização Brasileira, 1938.

Lóbrega, Manoel. "Diálogo sobre la conversión del gentío. Bahía, 1556-1557". En Serafim Leite, ed. Cartas dos primeiros jesuitas no Brasil. Vol. 2. São Paulo: Comissão do IV Centenário da Cidade de Sao Paulo, 1954.

Mello e Souza, Laura de. "Tensiones sociales en Minas en la segunda mitad del siglo XVIII". En Adauto Novaes, ed. Tempo e história. São Paulo: Companhia das Letras; Secretaria Municipal de Cultura, 1992.

O diabo e a terra de Santa Cruz. São Paulo: Companhia das Letras, 1989.

Moura, La P. "Folclorofilia e Romantismo". Boletim da Comissão Mineira de Folclore, no. 11 (1987).

Neves, L. F. Baêta. O combate dos soldados de Cristo na terra dos papagayos. Rio de Janeiro: Forense-Universitaria, 1978.

Novais, Fernando. "Condições da privacidade na Colônia". En Laura de Mello e Souza, ed. História da vida privada no Brasil (Cotidiano e vida privada na América Portuguesa). Sao Paulo: Companhia das Letras, 1997.

Ozouf, Mona. "A festa sob a Revolução Francesa”. En Jacques Le Goff y Pierre Nora. História: Novos objetos. Rio de Janeiro: Francisco Alves, 1988.

Pedrero-Sánchez. "Da Cruzada medieval à escravidão colonial". Cadernos de Pesquisa, no. 1 (1989).

Pereira, Niomar de Souza. Cavalhadas no Brasil. São Paulo: Escola de Folclore, 1984.

Priore, Mary del. Festas e utopias no Brasil colonial. São Paulo: Brasiliense, 1994.

Raminelli, Ronald. Imagens da colonização: a representação do índio de Caminha a Vieira. Rio de Janeiro: Zahar; São Paulo: Edusp/FAPESP, 1996. 
Sepp, S. J. Antônio. Viagem às missões jesuiticas e trabalhos apostólico. Traducción de La. Reymundo Schneider. São Paulo: Livraria Martins Editora, 1943.

Subirats, Eduardo. "A lógica da colonização". En Adauto Novaes, ed. Tempo e história. São Paulo: Companhia das Letras; Secretaria Municipal de Cultura, 1992.

Teixeira Gonçalves, José Artur. "Cavalhadas na América portuguesa: morfologia da festa". En István Jancso e Iris Cantor, eds. Festa: cultura e sociabilidade na América portuguesa. Vol. 2. São Paulo: Edusp; Hucitec, 2001.

Cavalhadas: das lutas e torneios medievais às iestas no Brasil colonia. Tesis presentada para optar al título de Maestría en Historia, Assis, Faculdade de Ciências e Letras, Universidade Estadual Paulista, 1998.

Vieira, Antonio. "Sermão da Bula da Santa Cruzada (1647)". En Sermões. Vol. 14. Porto: Lello \& Irmãos Editores, 1959.

Wachtel, Nathan. Los vencidos. Los indios del Perú frente a la conquista española (1530-1570). Madrid: Alianza Editorial, 1976.

Fecha de recepción del artículo: 16 de junio de 2003

Fecha de aceptación: 22 de agosto de 2003 